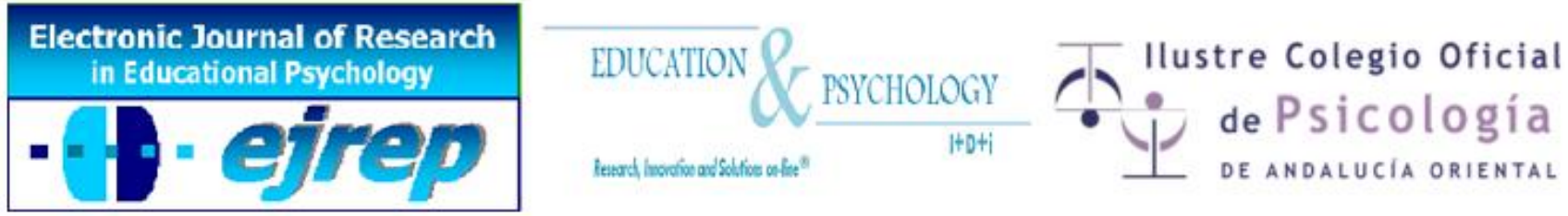

\title{
Spatial Visualization Abilities of Field Dependent/Independent Preservice Teachers
}

\author{
Ersen Yazici \\ ${ }^{1}$ Department of Elementary Mathematics Education, \\ Adnan Menderes University, Aydın
}

\section{Turkey}

Correspondence: Ersen Yazici. Department of Elementary Mathematics Education, Adnan Menderes University, Faculty of Education, 09100, Aydin. Turkey. E-mail: ersenyazici@gmail.com

(C) Education \& Psychology I+D+i and Ilustre Colegio Oficial de Psicología de Andalucía Oriental (Spain) 


\section{Abstract}

Introduction. Spatial skills have been a significant area of research in educational psychology for more years and it has two major dimensions as spatial visualization and spatial orientation. Mathematics educators acknowledge the influence of cognitive styles in the learning of mathematics. There are various recognized cognitive styles in the literature and field dependence/independence is a cognitive style defined as a measure of one's ability to disembed relative information from irrelevant background and to analyze and cognitively restructure information.

Method. The aim of this study was to define the spatial visualization abilities of preservice teachers who were receiving training in different fields and to investigate these abilities in view of different variants. For these purposes, 447 preservice teachers participating in the study were given the Group Embedded Figures Test (GEFT) and Purdue Spatial Visualization Test (PSVT). Preservice teachers were grouped as field dependent/independent according to their learning styles, and their spatial visualization scores were determined. Comparisons between the groups were carried out using multivariate analysis of variance (MANOVA).

Results. Spatial visualization scores of preservice teachers did not indicate any difference depending on their fields, that is, they showed preservice teachers receiving training in science and social fields had similar spatial visualization scores. Meanwhile, the comparisons made it clear that spatial visualization scores differentiated between females and males and depending on the preservices' preferences for field dependent/independent learning styles. All three score types (developments, rotations and views) are higher for males than the means belonging to females. The means for field independent preservice teachers were found to be higher than field dependent ones for all three scores types related to spatial visualization test.

Discussion and Conclusion. In this study, it was obtained as a result that males had higher spatial visualization abilities than females, and our results are in harmony with the general literature in this field. The accessible scientific studies in the literature indicate a significant relation between field dependency and spatial visualization ability, and the results of our study concur with the literature.

Keywords: spatial visualization ability, field dependent/independent, preservice teachers, sex differences.

Received: 12/05/13 Initial acceptance: 04/07/14 Final acceptance: 06/28/14 


\section{Habilidades de visualización espacial de futuros docentes de campo dependiente/independiente}

\section{Resumen}

Introducción. Las habilidades espaciales han sido un área importante de la investigación en psicología de la educación durante bastantes, con dos grandes dimensiones como la visualización espacial y la orientación espacial. Los educadores de matemáticas reconocen la influencia de los estilos cognitivos en el aprendizaje de las matemáticas. Hay varios estilos cognitivos reconocidas en la literatura y el campo de la dependencia / independencia es un estilo cognitivo se define como una medida de la capacidad para procesar la información relativa a fondo irrelevante y para analizar y reestructurar la información cognitiva.

Método. El objetivo de esta investigación fue definir las habilidades de visualización espacial de futuros profesores que estaban recibiendo formación en diferentes campos e investigar estas habilidades en vista de las diferentes variantes. Para ello, 447 futuros profesores que participaron en el estudio se les realizó el test Figuras Group Embedded (GEFT) y Purdue espacial Visualización Test (TSVP). Los futuros profesores se agruparon como dependientes / independientes de campo de acuerdo a sus estilos de aprendizaje, y se determinaron sus puntuaciones de visualización espacial. Las comparaciones entre los grupos se realizaron mediante análisis multivariado de varianza (MANOVA).

Resultados. Las puntuaciones de visualización espacial de futuros profesores no indicaron ninguna diferencia en función de sus campos, es decir, mostraron que los futuros maestros reciben capacitación en ciencia y campos sociales tenían puntuaciones de visualización espacial similares. Mientras tanto, las comparaciones han dejado claro que las puntuaciones de visualización espacial diferenciados entre mujeres y hombres, en función de las preferencias de los estudiantes según sus estilos de aprendizaje independiente vs dependientes de campo. Los tres tipos de puntuación (desarrollos, rotaciones y vistas) son mayores para los hombres que los medios que pertenecen a mujeres. Se encontró que las medias de los futuros profesores independientes de campo fueron más altas que los dependientes de campo para los aspectos referidos a la prueba de la visualización espacial.

Discusión y conclusiones. En este estudio, se obtuvo como resultado que los hombres tenían mayores habilidades de visualización espacial que en mujeres y nuestros resultados están en consonancia con la literatura general en este campo. Los estudios científicos accesibles en la literatura indican una relación significativa entre la dependencia del campo y la capacidad de visualización espacial, y los resultados de nuestro estudio coinciden con la literatura.

Palabras Clave: capacidad de visualización espacial, campo, futuros profesores dependientes / independientes, las diferencias de sexo. 


\section{Introduction}

By one estimate there are at least 84 different careers for which spatial skills play an important role (Smith, 1964). According to Maier (1994), for technical professions, such as engineering, spatial visualization skills and mental rotation abilities are especially important (cited in Sorby, 2005). Spatial intelligence is the type of intellectual ability primarily used by humans to function and operate in two or three dimensional space. Surgeons, pilots, architects, engineers, mechanics, builders, geometricians, professional drivers, farmers, factory workers, trades people, servicemen and women, some scientists and many others rely on spatial intelligence as their primary mode of operating in their workday lives. As estimated, approximately $80 \%$ of human jobs are primarily dependent on spatial intelligence, not verbal intelligence (Bannatyne, 2003). Spatial abilities, beside the professions needing expertise, encouter us on many occasions in our daily lives from changing the places of household goods to driving securely; from placing the plates into a dishwasher to playing billards, and are used, unnoticedly, in a good or bad way (Y1ld1z, 2009). Therefore, in addition to their being extremely effective in their professional lives of many job groups, spatial ability, which we use quite frequently in our daily lives, can not be thought to be ignored in teaching mathematics, in particular geometry. NCTM (2000), identified the development of spatial abilities as a central goal in school mathematics especially in geometry. The reality that spatial abilities have so great an importance in mathematics education and that they are used effectively in different professional groups inspired this study which focuses on the spatial abilities of preservice teachers receiving education in different fields.

Spatial skills have been a significant area of research in educational psychology since the1920s or 30s. However, unlike with other types of skills, there is no real consensus about what is meant by the term spatial skills and its substructures (Sorby, 1999). This is a general term that refers to an individual's mental ability to visualize, transform, and manipulate nonverbal information, such as symbols, figures, and 2-D and 3-D objects based on visual stimuli (Carroll, 1993; Linn \& Petersen, 1985; McGee, 1979). Lohman (1979) defined spatial ability as: the ability to generate, retain, and manipulate abstract visual images. At the most basic level, spatial thinking requires the ability to encode, remember, transform, and match spatial stimuli. According to many researchers, spatial ability has two major dimensions as spatial visualization and spatial orientation (Clements, 1998; Lohman, 1979; McGee, 1979). Linn \& 
Petersen (1985), added spatial perception and Olkun \& Altun (2003) added spatial relations as major dimensions of spatial ability (cited in Y1ld1z, 2009). In this present study, the researcher will focus on spatial visualization. McGee (1979) describes spatial visualization, a particular subset of spatial skills, as "the ability to mentally manipulate, rotate, twist, or invert a pictorially presented stimulus object". Mental rotation, one of the substructures of spatial ability, involves a cognitive process to mentally rotate two or three dimensional objects to whatever direction at will. Mental transformation, another substructure of spatial ability, involves manipulation of only parts of figures, whereas mental rotation involves manipulation of an object as a whole (Tartre, 1990). In other words, spatial visualization abilities, meaning to "involve complicated, multi-step manipulations of spatially presented information", involve in the processes required for spatial perception and mental rotations but are distinguished by the possibility of multiple solution strategies, stressing that multi-step, analytic procedures are required to solve the tasks. And, examples of tests for spatial ability are Embedded Figure Test, Hidden Figures, Paper Folding, Paper Form Board, Block Designing, Surface Development Test, DAT:SR, Guilford-Zimmerman spatial visualization (Linn \& Peterson, 1985). Although The Embedded Figure Test and Hidden Figures Tests are the ones that are used to define the participants' learning styles, they are also the ones that necessitate the usage of spatial abilities efectively. This case indicates a relation between cognitive learning styles and spatial abilities. In the determination of the subject of this study, this situation played a striking role.

Mathematics educators acknowledge the influence of cognitive styles in learning mathematics. There are various recognized cognitive styles available in the literature, among which are visual/haptic, visualizer/verbalizer, leveling/sharpening, serialist/holist, and field dependent/independent (Altun \& Çakan, 2006). Field dependence/independence as a dimension of cognitive style has been studied by many researchers. Field dependence/independence is a cognitive style defined as a measure of one's ability to disembed relative information from irrelevant background and to analyze and cognitively restructure information (Witkin \& Goodenough, 1981). According to (Altun \& Çakan, 2006), the general tendencies of field dependent and independent learners as follows:

Field-dependents: 1) Rely on the surrounding perceptual field; 2) Have difficulty attending to, extracting, and using non salient cues; 3) Have difficulty providing structure to ambiguous information; 4) Have difficulty restructuring new information and forging links 
with prior knowledge; 5) Have difficulty retrieving information from long-term memory. Conversely, field-independents; 6) Perceive objects as separate from the field; 7) Can disembed relevant items from non-relevant items within the field; 8) Provide structure when it is not inherent in the presented information; 9) Reorganize information to provide a context for prior knowledge; 10) Tend to be more efficient at retrieving items from memory (Daniels, 1996).

\section{The Aims}

In determining whether the participants are field dependent or independent, a scale developed by Oltman, Raskin and Witkin (1971) was used. The high number of the correct answers of the participants to the test, which should contain simple figures in complex ones, indicate that they were able to define the simple shapes in complex ones, in other words that they are field independent. Similarly, a low scoring in the test, however, would lead us to conclude an indiscrimination ability of simple and complex figures, that is, the field dependence. The aim of this study is to define the learning styles of preservice teachers receiving training in different fields, to determine their spatial abilities, and do examine those abilities in terms of sex, field and learning style variants.

\section{Method}

\section{Participants}

Convenience sampling (Patton, 1990) was selected as the sampling model in this research. Because with this model, researchers build up a sample that is satisfactory to their specific needs (Cohen, Manion \& Morrison, 2000). On the other hand, the most appropriate purposeful sampling strategy to this study is convenience sampling in which available individuals are taken or the cases are taken as they occur (Patton, 1990). So, research was carried out on 447 preservice teachers studying in different teaching programs. These programs are (1) elementary mathematics teacher education, (2) elementary science teacher education, (3) primary education, (4) early childhood teacher education and (5) computer education and instructional technology. All the preservice teachers receiving education in the so-called programs of two state universities were taken as the study universe. The study universe was composed of approximately 2800 preservice teachers. 447 preservice teachers were selected randomly from this study universe according to appropriate sampling method and the sampling was made in this way. According to Krejcie \& Morgan (1970), it was stated that a sampling that represents a study universe of 2800 individuals should contain at least 338 indi- 
viduals (cited in Cohen, Manion \& Morrison, 2000). This case justifies the sufficiency of our sampling method in representing the study universe.

Preservice teachers were divided into two groups as science and social fields according to the programs they were given. In this grouping, subjects being taught in the programs and the point types in the central placement exams were taken into consideration. According to this grouping, the first two of the programs (elementary mathematics teacher education and elementary science teacher education) were regarded as science field and the other three (primary education, early childhood teacher education and computer education and instructional technology) were defined as the social field. Distrubution of preservice teachers according to their programs, fields and sex was given in Table 1. The preservice teachers included in the sampling completed the data collecting tools voluntarily.

Table 1. Distrubution of preservice teachers according to their programs, fields and sex

\begin{tabular}{lcc|cccc}
\hline & \multicolumn{2}{c}{ Science $(\mathrm{n}=181,40.5 \%)$} & \multicolumn{3}{c}{ Social $(\mathrm{n}=266,59.5 \%)$} & Total \\
\hline \multirow{2}{*}{ EME } & ESE & PE & ECE & CE & 297 \\
& 48 & 85 & 122 & 30 & 12 & $66.4 \%$ \\
Male & 22 & 26 & 75 & 5 & 22 & 150 \\
& & & & & & $33.6 \%$ \\
Total & 70 & 111 & 197 & 35 & 34 & 447 \\
& $15.7 \%$ & $24.8 \%$ & $44.1 \%$ & $7.8 \%$ & $7.6 \%$ & $100.0 \%$ \\
\hline
\end{tabular}

EME: Elementary Mathematics Teacher Education, ESE: Elementary Science Teacher Education, PE: Primary Education, ECE: Early Childhood Teacher Education, CE: Computer Education and Instructional Technology

\section{Instruments}

The independent variants of the study were the sex of the preservice teachers, their educational fields, and their learning styles, while dependent variant was spatial visualization abilities because the relation between the spatial visualization abilities of the preservice teachers and some variants were being investigated in the study. As learning style variant, field dependency, which was one of the learning style preferences of individuals, was used. In determining whether preservice teachers are field dependent or not, Group Hidden Figures Tests, and in determining spatial visualization abilities Purdue Spatial Visualization Tests were used. For the collection of the demographic data, an information collection form was used together with those so-called scales. 


\section{1) The Group Embedded Figures Test (GEFT)}

In determining learning styles of preservice teachers The Group Embedded Figures Test was used. The Turkish adaptaion of this test, which was developed by Oltman, Raskin and Witkin (1971), was made by Okman Fişek (1979). The test is used to define which cognitive dimension the responder is in; whether in field dependent or field independent. The test used in our study is a form of Hidden Figures Test, an individual test, developed by Oltman and his friends for group application.

The test is consisted of totally three parts containing 25 complex figures and 9 simple figures. The subjects are expected to find and mark the simple figure hidden in the given complex figures in a certain period of time. While the complex figures are given in three parts, simple figures are given on a page at the end of the test, each of which named by a different letter. In responding, the participants make out the simple figure marked with a letter beside the complex figure by over-drawing it with a pencil.

\section{2) Purdue Spatial Visualization Test (PSVT)}

In determining spatial visualization abilities, Purdue Spatial Visualization Test was used. This tool, used in determining visual-spatial abilities of individuals, was developed by 8 ,) and its translation into Turkish for application was made by the author. The test itself is a valid and reliable means of measurement in determining the mentioned characteristic (Guay, 1980; Sorby, 2001). The reality that this tool has been used in many studies subjecting spatial visualization abilities support this view (Güven \& Kösa, 2008; Moyer, 2003; Sorby, 1999). The reliability coefficients Guay (1976) calculated for participants having different learning levels range between 0.80 and 0.92 , and the coefficient for preservice teachers he found is 0.80. In this study, where 447 participants were included by the researcher, the alpha reliability coefficient was calculated as 0.79 .

The test is composed of developments, rotations, and views sections respectively. It contains totally 36 questions, as 12 in each section. Responders are given 8 minutes time and total 24 minutes to answer the questions. The questions have been prepared for responders who are 13 years old and over and have been arranged in difficulty order-from easy to diffi- 
cult. In each section, a directory related to that section and 2 examples have been presented to responders.

\section{Procedure}

The instruments were given to participants in different sessions according their educational fields. Therefore, five different sessions organised for applications. Sessions divided to two steps. In first step, The Group Embedded Figures Test (GEFT) and in second step Purdue Spatial Visualization Test (PSVT) has been applied.

Step 1: There are 7 complex figures in the first part of GEFT. These figures are not included in scoring and are examples presented for the participants. The time period given to participants to respond to this section is 2 minutes. By the practitioner's guidance, participants who complete the first section in this period of time answer the other two sections making up the essence of the complete test, each of which is made up of 9 complex figures, and for each of which 5 minutes of time period is given. A participant, getting 1 point for each correct answer, can only score 18 points most in this test. A rise in the scores indicates field independence of the participant, while a fall means field dependence. There is no spectrum in defining field dependence or independency, and different approaches are observed in different studies in this matter (Ling \& Salvendy, 2009; Somyürek \& Yalın, 2007; Çakan, 2005; Güven, 2003). The participant was regarded as field independent if s/he scored over 9 and field dependent if $\mathrm{s} /$ he scored 9 or less in defining the cognitive styles of preservice teachers.

Step 2: PSVT has three sections. What the responders are expected to do in the "developments section" is that they should form the object, whose open state is given on a plane and whose base is mentioned, by fondling to be applied to opening and should find it among the alternatives and mark it. In this section, the preservice teachers try to imagine in their minds how the given open state will look when it is fodled as a three dimensional object. The section titled as "rotations" is based upon the rotation of three dimensional objects and imagining the new shape in mind. In this section, three objects are given in each question. Of the objets given in the first rank, the one on the left is turned according to a principle and the shape just on the right is produced. The preservices are asked to find this principle and to apply it to the object given below and to imagine the object's new look in their minds and then to mark the choice among the given answers that matches with that image. The rules of the rotations change as 90 or 180 degrees in the direction of $\mathrm{x}, \mathrm{y}$, or $\mathrm{z}$ axis. The section heading as 
"views" have been prepared to define how participants can imagine three dimensional objects visually in their minds in different points of view. The object is given in this section as placed right in the middle of a cubic transparent box. The cube has a black spot in one corner. The participants are expected to imagine in their minds how the object will appear when looked through that black spot, in other words, how it will look when the transparent box is turned until that black spot comes between the viewer and the object.

\section{Statistical Analysis}

Sex variant of preservice teachers was determined by a classification done directly with the survey in which demographic data were collected, while the field variant according to program information gathered in the survey. As for learning styles of preservices, they were classified as field dependent and field independent by scoring the answers they gave to GEFT. In determining the spatial visualization ability, a value was found for each section of the scale by scoring the answers the candidates gave to PSVT. In this way, a spatial visualization development point, rotation point and view point were found as the indication of spatial visualization ability for each preservice teacher. While sex, education field and learning style were taken as independent variants, spatial visualization development grade, rotation grade and view grade were taken as dependent variants.

Since it was tried to determine in this study whether these groups, classified according to above independent variants, indicated any differences in terms of formation, rotation and view points, Multivariate ANOVA (MANOVA) was used in comparing differences among groups. In the comparison of group means, Wilks Lambda $(\Lambda)$ and F statistics were used. In providing MANOVA conjectures, Mahalanobis distance was used in controlling outliers, and so was Box's M test in controlling homogeneity of co-variant matrices, Levene test in controlling the homogeneity of the variants, and Mardia's kurtosis and skewness coefficients in controlling multivariate normality. SPSS package program was used in analyzing. In determining single and multivariate normalities and in calculating Madia's coefficients, macros written by DeCarlo (1997) were used. 


\section{Results}

While spatial visualization development, rotation and view grades of preservice teachers were taken as dependent variants, their sex, field and learning styles were taken as independent variants. Multivariate Analysis of Variance (MANOVA) was used, for it was being searched whether there was a difference among groups classified according to more than two independent variants in terms of more than two dependent variant (development, rotation and view points). One of MANOVA's assumptions is multivariate normality. In this study, multivariate normality related to dependent variants was determined by Mardia kurtosis and skewness coefficients. Coefficients were calculated as $($ skew $=.79$; chi-square $=58.91 ; p<.01)$ and (kurtosis $=14.82 ; p>.05$ ). This case indicates that spatial visualization points are distributed differently than normal. To be able to continue the analysis the normality has to be provided. Outliers were examined for this purpose. Mahalanobis distances were used in this examination. The biggest mahalanobis was found for 76 numbered participant and this value was not regarded as significant $(p>.001)$. This case shows that there is no outlier to disrupt normality. Transformation was applied to in order to provide normality hypothesis. At the transformation stage, square-root transformation was applied, by adding fixed 1 to all spatial visualization points because there was no zero in the point set. For this reason, by symbolizing all spatial visualization points before transformation as $y$ and all points after transformation as $y^{\prime}$ the transformation rule can be expressed with $y^{\prime}=\sqrt{y+1}$ equation. From this point on, all calculations were done on the transferred data.

According to the examinations carried out following the transformation, Mardia kurtosis and skewness coefficients related to spatial visualization development, rotation and view grades of preservice teachers (skew=.24; chi-square=17.93; p>.05) and (kurtosis=14.20; $p>.05$ ) indicated that multivariate normality hypothesis was provided. Box's M test was applied to for the control of homogeneity of covariance matrises, which is another hypothesis. The calculated statistics (Box's $M=49.67 ; p>.05$ ) indicate homogeneity of covariance matrises. Upon fulfilling all hypotheses, MANOVA test was used to determine differences in terms of dependent variants, and ANOVA test in case there were differences among means. Since the sizes of the groups in which MANOVA was conducted were different than each other and as no interaction was predicted among independent variants, MANOVA-Type II was preferred. MANOVA results are shown in Table 2. 
Table 2. MANOVA results of PSVT

\begin{tabular}{llccccc}
\hline & & Value & F & Hypo. df & Error df & $\eta^{2}$ \\
\hline \multirow{2}{*}{ Program } & Pillai's Trace & .009 & 1.289 & 3 & 437 & .009 \\
\hline \multirow{2}{*}{ Sex } & Pillai's Trace & .118 & $19.576^{* * * *}$ & 3 & 437 & .118 \\
\hline Style & Pillai's Trace & .263 & $52.002^{* * * *}$ & 3 & 437 & .263 \\
\hline \multicolumn{2}{r}{$* * * p^{<.001}$} & & & & &
\end{tabular}

According to MANOVA results given in Table 2, the multiple comparisons done indicated that spatial visualization points of preservice teachers did not differentiate in the extent of field variant $\left(\Lambda=.991 ; F(3,437)=1.289 ; p>.05\right.$ and $\left.\eta^{2}=.009\right)$; but differed respectively in sex $\left(\Lambda=.882 ; \quad F(3,437)=19.576 ; \quad p<.001\right.$ and $\left.\eta^{2}=.118\right)$ and in learning style $(\Lambda=.737 ;$ $F(3,437)=52.002 ; p<.001$ and $\left.\eta^{2}=.263\right)$ extents. In addition, in the extent of variants found by pairwise interaction of these three variants, the differences were not found significant.

Findings related to MANOVA indicated that spatial visualization points of preservice teachers did not differentiate depending of the fields they were being educated in, that is, spatial visualization points of preservice teachers in science and social fields were similar. However, they indicated that spatial visualization points differed between males and females and according to the preferences of preservice teachers about field dependent/independent learning styles. Sex variant was seen to have a 0.12 and learning style variant to have a 0.26 effect size. In order to define which dependent variant the differences were for, each spatial visualization point was applied to ANOVA and the results were presented in Table 3. According to Levene test applied before ANOVA, the calculated F statistics $\left(F_{D e v}(7,439)=.321 ; p>.05\right.$; $F_{\text {Rot. }}(7,439)=.910 ; p>.05$ and $\left.F_{\text {View }}(7,439)=1.796 ; p>.05\right)$ show that variants are homogenous.

Table 3. ANOVA results of PSVT

\begin{tabular}{llcccc}
\hline & & Sum of squares & df & Mean square & F \\
\hline Sex & Developments & 2.578 & 1 & 2.578 & $12.702^{* * * *}$ \\
& Rotations & 9.014 & 1 & 9.014 & $42.335^{* * *}$ \\
& Views & 7.735 & 1 & 7.735 & $27.774^{* * *}$ \\
\hline Style & Developments & 16.743 & 1 & 16.743 & $82.493^{\text {**** }}$ \\
& Rotations & 19.652 & 1 & 19.652 & $92.296^{* * *}$ \\
& Views & 15.588 & 1 & 15.588 & $55.970^{* * *}$ \\
\end{tabular}


ANOVA results indicate that the calculated $F$ points are significant in terms of both sex and learning style variants in all spatial visualization point types (developments, rotations, and views $) \quad\left(F_{\text {Sex;Dev. }}=12.702 ; \quad F_{\text {Sex } ; \text { Rot. }}=42.335 ; \quad F_{\text {Sex } ; \text { View }}=27.774 ; \quad F_{\text {Style } \text { Dev. }}=82.493\right.$; $\left.F_{\text {Style;Rot. }}=92.296 ; F_{\text {Style; } \text { View }}=55.970 ; p<.001\right)$. To define for which groups the differences were in favour pairwise comparisons were made. In pairwise comparisons, estimated marginal means of PSVT was used. While comparisons were being done, bonferroni correction was made at $\alpha$ significance level because the dependent variant number was 3, and $\alpha=0.05 / 3=0.017$ was taken as new significance level. Results are shown in Table 4.

Table 4. Pairwise comparisons of estimated marginal means of PSVT

\begin{tabular}{llccc}
\hline & & Developments & Rotations & Views \\
\hline Sex & Male $(i)$ & 2.318 & 2.396 & 2.683 \\
& Female $(j)$ & 2.174 & 2.083 & 2.378 \\
& Differ. $(i-j)$ & $0.144^{* *}$ & $0.313^{* * *}$ & $0.305^{* * *}$ \\
\hline Style & Independent $(i)$ & 2.451 & 2.468 & 2.742 \\
& Dependent $(j)$ & 2.041 & 2.011 & 2.319 \\
& Differ. $(i-j)$ & $0.410^{* * *}$ & $0.457^{* * *}$ & $0.423^{* * *}$ \\
\hline
\end{tabular}

** $p<.01, * * * p<.001$

When pairwise comparisons in terms of sex variant were examined, it was seen that means belonging to males are higher than the means belonging to females for all three point types (developments, rotations and views) related to spatial visualization test. The comparisons made underline significant differences in all three point types in favour of males $(p<.01)$. This result enables us, within the limitations of the present study, to express that spatial visualization abilities of males are more developed than females. If a similar evaluation is made for learning style variant, it can be seen that the average points of field independent preservice teachers are higher in all three types than the average points of field dependent preservice teachers. The significance of differences in all three types in favour of field independent preservice teachers $(p<.001)$ indicates that spatial visualization abilities of individuals are more developed than field dependent ones. 


\section{Discussion and Conclusions}

In the content of the study, spatial visualization abilities of preservice teachers were examined in terms of three variants and in this section, the results obtained were discussed with the related studies included in literature. The discussion was made separately in three independent variant stages. The first result reached in the study, depending on multivariate analysis of variance, is that spatial visualization points of preservice teachers don't change for field variant. In other words, within the limitations of the results of present study, there is no difference between the spatial visualization abilities of science field preservice teachers and spatial visualization abilities of social field preservice teachers. When the literature was examined in terms if the mentioned variant, it was seen that the participants were directly grouped under science and social field headings and the comparisons were made on this plane, and for this reason it was not possible to make a comparison with an identical study. However, in a study employing 1022 participants from different fields (Yoon, 2011), the means belonging to participants (PSVT:R) was calculated as 19.08 and the standard deviation as 6.16. Although a statictical comparison wasn't done in terms of fields, participants in engineering, management, science and technology fields scored higher than the means while participants in other fields (agriculture, consumer and family sciences, education, liberal arts, pharmacy, nursing and health sciences) scored less than the mean. This result reminds us that spatial abilities of individuals in enginnering, science and technology fields could be more developed. According to Sorby (2010); numerous studies have shown that highly developed spatial skills are important to success in a number of STEM (Science, Technology, Engineering and Mathematics) fields. However possible the spatial abilities of the individuals in the so-called fields could sound to be more developed, the present study does not support this case.

Another result reached in the content of the study is that males have higher spatial visualization abilities than females. In the scientific studies done particularly in educational field, it is possible to come up with the ones searching for the effects of sex difference on dependent variant quite frequently. During the recent years in particular, the number of these studies has increased. Not only are there studies searching for the effects of sex difference besides other independent variants, there are also studies subjecting at sex difference alone. It is even possible to reach journals just publishing studies issuing sex differences. In many of the scientific studies subjecting sex differences to date, it is generally expressed that males are more successful than females in terms of mentioned variants. However, since females started 
to benefit education opportunities more equally with males, this difference has reduced. No significant differences are seen anymore in terms of many variants. Similarly, there are studies showing there is no difference between males and females in terms of spatial abilities (Alias, Black \& Gray, 2002); however, the case appears differently in general.

There is a great deal of evidence to suggest that the spatial skills of women lag significantly behind those of their male counterparts (Sorby, 2005). It is possible to reach studies indicating that there is difference between males and females in terms of spatial abilities (Alansari, DerEgowski \& McGeorge, 2008; Battista, 1990; Yoon, 2011; Sorby, 2006; 2010; Veurink et al, 2009). In present study, it was reached the result that spatial visualization abilities of males are higher than of females and this case is parelel with the literature. According to Sorby (2010); of all cognitive processes, spatial skills, particularly mental rotation, exhibit some of the most robust gender differences favouring males. Numerous studies have found significant mental rotation gender differences over the years. In research conducted by the author over the past several years, these gender differences are significant and consistent. Although there is no common consensus as to the root of the gender differences in spatial skills, they are persistent across international boundaries. As cited in Sorby (2005); theories for the cause of these differences include the assertion that spatial ability is transmitted as a recessive characteristic on the X-chromosome (Stafford, 1972), that spatial ability is related to a male sex hormone (Hier \& Crowley, 1982), or that environmental factors are the primary reasons for male-female differences in spatial skill levels (Fennema \& Sherman, 1977). Some researchers suggest that biological differences between women and men may contribute to gender differences in mental rotation ability. The biological factors include physical attributes, such as differences in functional and morphological structures of the brain, hormones, genes and age (Yoon, 2011).

Another result found in the study is that field independent participants are more successful than field dependent ones in terms of spatial visualization ability. According to the results of hidden figures test in present study, it can be said that participants defined as field independent, that is, individuals who can easily define simple figures in complex figures, are more successful in terms of spatial visualization ability than the ones who can not. A study reporting similar results was done by Idris (1998). The purpose of this study was to investigate the relative importance of the cognitive variables of spatial visualization, field dependence/independence, and Van Hiele level of geometric thought in predicting achievement in 
geometry. A significant positive correlation $(r=.245, p<.01)$ existed between spatial visualization (SVA) and field dependence/independence (FDI) for the total sample of 137 students. As cited in Idris (1998); field independent learners have more highly developed cognitive restructuring ability, exhibit better personal autonomy, are more skilled at extracting the salient features of a problem, are more analytical, and are more successful in mathematics (Davis \& Frank, 1979; Moore \& Moore, 1984). Field independent persons are able to remember spatial information and accurately place map features that they recalled during the reconstruction task (Shaha, 1982). On the other hand, field dependent learners are more global in their perceptions, are more influenced by the complex design; that is, the situation is perceived as presented (Witkin, Moore, Goodenough \& Cox, 1977). Investigation by Witkin et al. (1977) have indicated that field dependence/independence, the ability to disembed common geometric shapes embedded within a larger geometric design, is a significant contributor to achievement in science, mathematics, engineering and architecture. Field dependence/independence can be considered a possible factor affecting the ability to do well in geometry, for example in a formal geometry course where the ability to find hidden figures is needed. Hozaki (1987) investigated the interaction between cognitive styles (field dependence/independence) and visualization on a paper-folding task on a group of 109 field dependent and independent male and female college students of Ohio State University. Hozaki found that field independence seems to play an important role in perceptual disembedding skill and visualization skills in physical performance of a moderately complex paper-folding task. By Arrington (1987), the strength of the relationships between field dependence/independence, spatial visualization, and problem solving of 100 adolescents in grade eight. Results indicated that cognitive style and spatial visualization were positively related to problem solving. Field independent subjects with high visualization ability scored higher than field dependent, low spatial visualization ability adolescents. The mentioned scientific studies indicate the presence of a significant relation between field dependency and spatial visualization ability and the results of the present study are in parelel with the literature. To define the learning preferences of individuals in a learning environment and to plan convenient teaching activities matching with them will contribute to the development of spatial visualization abilities. 


\section{References}

Alansari, B. M., DerEgowski, J. B., \& McGeorge, P. (2008). Sex differences in spatial visualization of Kuwaiti school children. Social Behaviour and Personality, 36(6), 811-824. doi:10.2224/sbp.2008.36.6.811

Alias, M., Black, T. R., \& Gray, D. E. (2002). Effect of instructions on spatial visualization ability in civil engineering students. International Educational Journal, 3(1), 1-12.

Altun, A., \& Çakan, M. (2006). Undergraduate students' academic achievement, field dependent/independent cognitive styles and attitude toward computers. Educational Technology \& Society, 9(1), 289-297.

Arrington, H. J. (1987). Relationship between field dependence/independence, visualization, and problem solving in adolescent males and females. Dissertation Abstracts International, 49.

Bannatyne, A. (2003). Multiple intelligences. Bannatyne reading, writing, spellingand lan$\begin{array}{llll}\text { guage } & \text { program. } & \text { Retrieved }\end{array}$ http://www.bannatynereadingprogram.com/BP12MULT.htm.

Battista, M. T. (1990). Spatial visualization and gender differences in high school geometry. J. Res. Math. Educ., 21, 47-60. doi:10.2307/749456

Carroll, J. B. (1993). Human Cognitive Abilities: A Survey of Factor-analytic Studies. New York: Cambridge Univ. Press.

Clements, D. H. (1998). Geometric and spatial thinking in young children. (ERIC Servis No. ED436232)

Cohen, L., Manion, L., \& Morrison, K. (2000). Research Methods in Education (5th Edition). London: RoutledgeFalmer.

Çakan, M. (2005). Bilişsel stiller ile yabancı dil başarısı arasındaki ilişki: 8.sınıf Fransızca örneği. Illköğretim Online, 4(1), 53-61.

Daniels, H. L. (1996). Interaction of cognitive style and learner control of presentation mode in a hypermedia environment, retrieved from: http://scholar.lib.vt.edu/theses/available/etd-3132141279612241/.

Davis, J. K., \& Frank, B. M. (1979). Learning and memory of field independent-dependent individuals. Journal of Research in Personality, 13, 469-479. doi:10.1016/0092$\underline{6566(79)}$

DeCarlo, L. T. (1997). On the meaning and use of kurtosis. Psychological Methods, 2(3), 292307. Retrieved July 3, 2013, from http://www.columbia.edu/ ld208/. 
Fennema, E., \& Sherman, J. A. (1977). Sexual stereo-typing and mathematics learning. The Arithmetic Teacher, 24(5), 369-372.

Guay, R. B. (1976). Purdue Spatial Visualization Test. West Lafayette, IN: Purdue Research Foundation.

Guay, R. B. (1980). Spatial ability measurement: a critique and alternative. Paper presented at The Annual Meeting of the American Educational Research Association, Boston, MA. (ERIC Document Reproduction Service No: ED189166).

Güven, B. (2003). İlköğretim 5. Sinıf sosyal bilgiler dersinde alan bağımlılık - alan bă̆ımsızlık bilişsel stil boyutlarına uygun olarak hazırlanan öğretim etkinliklerinin akademik başarı ve tutumlar üzerindeki etkisi. Yayınlanmamış Doktora Tezi. Anadolu Üniversitesi Eğitim Bilimleri Enstitüsü: Eskişehir.

Güven, B., \& Kösa, T. (2008). The effect of dynamic geometry software on student mathematics teachers' spatial visualization skills. The Turkish Online Journal of Educational Technology, 7(4), 1303-1310.

Hier, D. B., \& Crowley, Jr.W. F. (1982). Spatial ability in androgen-deficient men. New England Journal of Medicine, 306(20), 1202-1205.

Hozaki, N. (1987). The effects of field dependence/independence and visualized instruction in a lesson of origami, paper folding, upon performance and comprehension. Dissertation Abstracts International, 50.

Idris, N. (1998). Spatial visualization, field dependence/independence, Van Hiele level, and achievement in geometry: influence of selected activities for middle school students. Unpublished doctoral dissertation, Graduate School of the Ohio State University.

Krejcie, R. V., \& Morgan, D. W. (1970). Determining sample size for research activities. Educational and Psychological Measurement, 30, 607-610. (ERIC Document Reproduction Service No: EJ026025).

Ling, C., \& Salvendy, G. (2009). Effect of evaulators' cognitive style on heuristic evaulation: Field dependent and field independent evaulators. International Journal of HumanComputer Studies, 67, 382-393. doi:10.1016/j.ijhcs.2008.11.002

Linn, M. C., \& Petersen, A. C. (1985). Emergence and characterization of sex differences in spatial ability: A meta-analysis. Child Development, 56, 1479-1498. doi: $10.2307 / 1130467$

Lohman, D. F. (1979). Spatial Ability: A Review and Reanalysis of the Correlational Literature, in Aptitude Research Project, Technical Report No. 8, Aptitude Research Project; School of Education, Stanford University: Palo Alto, CA. 
Maier, P. H. (1994). Raeumliches vorstellungsvermoegen. Frankfurt a.M., Berlin, Bern, New York, Paris, Wien: Lang.

McGee, M. G. (1979). Human Spatial Abilities: Sources of Sex Differences. New York: Praeger.

Moyer, T. O. (2003). An Investigation of The Geometer's Sketchpad and Van Hiele Levels. Unpublished doctoral dissertation. Temple University, Philadelphia, Pennsylvania.

NCTM. (2000). Principles and Standards for School Mathematics. Reston, VA: National Council of Teachers of Mathematics.

Olkun, S., \& Altun, A. (2003). İlköğretim öğrencilerinin bilgisayar deneyimleri ile uzamsal düşünme ve geometri başarıları arasındaki ilişki. The Turkish Online Journal of Educational Technology, 2(4), 1-7.

Patton, M. Q. (1990). Qualitative Evaluation and Research Methods. Newbury Park, London, New Delhi: SAGE Publications.

Smith, I. M. (1964). Spatial Ability-Its Educational and Social Significance. London: University of London.

Somyürek, S., \& Yalın, H. İ. (2007). Bilgisayar destekli eğitim yazılımlarında kullanılan ön örgütleyicilerin alan bağımlı ve alan bağımsız öğrencilerin akademik başarılarına etkisi. Türk Ĕ̈itim Bilimleri Dergisi, 5(4), 587-607.

Sorby, S. A. (1999). Developing 3-D spatial visualization skills. Engineering Design Graphics Journal, 63(2), 21-32.

Sorby, S. A. (2001). Improving the spatial skills of engineering students: impact on graphics performance and retention. Engineering Design Graphics Journal, 65(3), 31-36.

Sorby, S. A. (2005). Assessment of a "new and improved" course forthe development of 3d spatial skills. Engineering Design Graphics Journal, 69(3), 6-13.

Sorby, S. A. (2006). Developing 3d spatial skills for K-12 students. Engineering Design Graphics Journal, 70(3), 1-11.

Sorby, S. A. (2010). Improving diversity in engineering through spatial skills training. Joint International IGIP-SEFI Annual Conference 2010, 19th - 22nd September 2010, Trnava, Slovakia.

Stafford, R. E. (1972). Hereditary and environmental components of quantitative reasoning. Review of Educational Research, 42, 183-201.

Tartre, L. A. (1990). Spatial skills, gender \& mathematics. In E. Fennema, \& G. Leder (Eds.), Mathematics and Gender: Influences on Teachers and Students (pp. 27-59). New York: Teachers' College Press. 
Witkin, H. A., Moore, C. A., Goodenough, D. R., \& Cox, P. W. (1977). Field-dependent and field-independent cognitive styles and their educational implications. Review of Educational Research, 47, 1-64.

Witkin, H. A., \& Goodenough, D. R. (1981). Cognitive Styles: Essence and Origin. New York: International Universities Press, Inc.

Veurink, N. L., Hamlin, A. J., Kampe, J. M., Sorby, S. A., Blasko, D. G., Holliday-Darr, K. A., . . . Knott, T. W. (2009). Enhancing visualization skills-improving options and success (EnVISIONS) of engineering and technology students. Engineering Design Graphics Journal, 73(2), 1-17.

Yıldız, B. (2009). Üç boyutlu sanal ortam ve somut materyal kullanımının uzamsal görselleştirme ve zihinsel döndürme becerilerine etkileri. Yayınlanmamış yüksek lisans tezi, Fen Bilimleri Enstitüsü, Hacettepe Üniversitesi, Ankara.

Yoon, S. Y. (2011). Psychometric Properties of the Revised Purdue Spatial Visualization Tests: Visualization of Rotations (The Revised PSVT:R). Unpublished doctoral dissertation, Purdue University. 